Trinity University

Digital Commons@ Trinity

English Faculty Research

English Department

$10-1988$

\title{
Accepting the Romantics as Philosophers
}

Michael Fischer

TrinityUniversity, mfischer@trinity.edu

Follow this and additional works at: https://digitalcommons.trinity.edu/eng_faculty

Part of the English Language and Literature Commons

\section{Repository Citation}

Fischer, M. (1988). Accepting the romantics as philosophers. Philosophy and Literature, 12(2), 179-189. doi: 10.1353/phl.1988.0016

This Article is brought to you for free and open access by the English Department at Digital Commons @ Trinity. It has been accepted for inclusion in English Faculty Research by an authorized administrator of Digital Commons@ Trinity. For more information, please contact jcostanz@trinity.edu. 
Michael Fischer

\section{ACCEPTING THE ROMANTICS AS PHILOSOPHERS}

$\mathrm{T}$

HE ROMANTICS ARE NOT widely regarded as philosophers, at least not in philosophy departments, where they are seldom taught. ${ }^{1}$ Some of the reasons behind this exclusion of the Romantics involve a general disdain for literature; other reasons suggest a more specific uneasiness with Romanticism itself - with its apparent interest in animism, its selfindulgence, its coolness toward reason, and, perhaps above all, its refusal to abide by Kant's containment of skepticism. These complaints are not the invention of paranoid or obtuse academic philosophers (as some literary critics might like to think). In fact, some of these objections have dogged the Romantics from the beginning. There is something risky, or outlandish, about Romanticism that these criticisms bring out.

I want here to pursue what is at stake in accepting the Romantics as philosophers. In discussing what may be threatening about Romanticism, I will be drawing on the work of Stanley Cavell. Unlike most professional philosophers, Cavell declares his indebtedness to the Romantics, but unlike some literary critics, he appreciates the dangers of the Romantic quest that he nevertheless joins. The Romantics often leave Cavell feeling nervous and wretched, as Thoreau left Emersonand as Cavell leaves many of his own readers. Cavell affirms Romanticism while acknowledging the risks that have repelled some of its critics: hence his usefulness to me here.

The Romantics' quarrel with Kant perhaps best accounts for the contempt, or indifference, that Romanticism can inspire in academic philosophers. Cavell pictures Kant as arriving at a settlement with skepticism, a compromise that concedes the inaccessibility of things-inthemselves, while reassuring us of our right to say that "we do know the existence of the world, or rather, that what we understand as knowl- 
edge is of the world." ${ }^{2}$ For Kant, again as Cavell portrays him, limiting knowledge-by relinquishing any claim to know things-in-themselvesis necessary to shoring up knowledge, to our still claiming that there is such a thing. By "knowledge" Kant, in effect, means science: he saves science by positioning it between skepticism (the denial of knowledge) and fanaticism or dogmatism (the expansion of knowledge beyond acceptable limits).

By affirming the possibility of (scientific) knowledge, Kant thus contains skepticism, or at least curtails its damage. But by putting thingsin-themselves beyond knowledge, he also gives in to skepticism. According to Cavell, the Romantics balk at this trade-off, saying, in effect, "Thanks for nothing." ${ }^{3}$ Knowledge of things-in-themselves is precisely the knowledge that the Romantics are most interested in. From this point of view, Kant concedes too much to skepticism - and gets too little in return. Resisting Kant accordingly entails putting us back in touch with things, or bringing us face-to-face with them, which in turn means showing that we can face things or shy away from them, presumably as we can confront or avoid people.

Cavell finds examples of Romantic writers facing things and even listening to them in Walden, the "Intimations" ode, and other texts." But I want to focus here on a poem that Cavell does not mention, "Tintern Abbey," where Wordsworth speaks of

that blessed mood,

In which the burthen of the mystery, In which the heavy and weary weight Of all this unintelligible world, Is lightened:-that serene and blessed mood, In which the affections gently lead us on,Until, the breath of this corporeal frame And even the motion of our human blood Almost suspended, we are laid asleep

In Body, and become a living soul:

While with an eye made quiet by the power

Of harmony, and the deep power of joy, We see into the life of things. (11. 37-49)

By "things" Wordsworth means nothing less than "all objects of all thought" (1. 101), "all that we behold / From this green earth"(1l. 1045), "all the mighty world / Of eye, and ear" (ll. 105-6). He specifically mentions "setting suns" (1. 97), "the round ocean and the living air, / 
And the blue sky" (11. 97-98) and he declares himself "a lover of the meadows and the woods, / And mountains" (ll. 103-4).

In these lines-and others I need not cite-the world is not simply intelligible to Wordsworth but alive. Even more strongly, its being alive makes it intelligible. Nothing else will lift the burden of its mysteryin particular, not science, which in this context seems not so much ominous as irrelevant. In the Preface to Lyrical Ballads, Wordsworth observes:

If the labours of Men of science should ever create any material revolution, direct or indirect, in our condition, and in the impressions which we habitually receive, the Poet will sleep then no more than at present; he will be ready to follow the steps of the Man of science, not only in those general indirect effects, but he will be at his side, carrying sensation into the midst of the objects of the science itself. The remotest discoveries of the Chemist, the Botanist, or Mineralogist, will be as proper objects of the Poet's art as any upon which it can be employed, if the time should ever come when these things shall be familiar to us, and the relations under which they are contemplated by the followers of these respective sciences shall be manifestly and palpably material to us as enjoying and suffering beings. If the time should ever come when what is now called science, thus familiarized to men, shall be ready to put on, as it were a form of flesh and blood, the Poet will lend his divine spirit to aid the transfiguration, and will welcome the Being thus produced, as a dear and genuine inmate of the household of man. ${ }^{5}$

If, Wordsworth is saying, the currently remote, or esoteric, discoveries of the scientist should become as familiar to us as the impressions we habitually receive, then the poet will sleep no more (he will still be busy) but he will also sleep no less (he will not be unduly worried). Until then, however, until science becomes "thus familiarized to man," science will remain "a personal and individual acquisition, slow to come to us, and by no habitual and direct sympathy connecting us with our fellowbeings" - or with the everyday objects of thought, the meadows, setting suns, and so on, that Wordsworth is most concerned to know. Science is neither a villian bringing on skepticism nor a savior keeping it at bay. Wordsworth stakes the intelligibility, or life, of the world on everyday sights and objects, on things a child might remark or draw. Science does not give us "the round ocean" and "the blue sky," and science cannot take them away.

If, for Wordsworth, science thus does not guarantee the intelligibility 
of the world, seeing into the life of things-which means seeing things as in some sense alive-apparently does. In countering skepticism with what looks like animism, Wordsworth, in Cavell's phrase, seems to have "exchanged one form of craziness for another" ("IQO," p. 193): hence the misgivings about Romanticism that I noted earlier. If the Romantics feel cheated by Kant's bargain with skepticism, philosophers may feel understandably alarmed by Wordsworth's response to Kant. I say understandably because, like Cavell, I want to emphasize that ever professed Romantics-not just academic philosophers-may feel apprehensive about this return of things-in-themselves by way of animism. In "Tintern Abbey" Wordsworth himself goes on to question whether his intimacy with the world may "be but a vain belief" (1. 50). And Cavell notes how in The Claim of Reason he "shrank" from animism in working out his own response to skepticism ("IQO," p. 193). Animism, he points out, "makes a momentary, somewhat disguised or frightened appearance in a late speculation in the final part of The Claim of Reason" (p. 192), as if Cavell, too, were embarrassed by it or reluctant to take it up.

Instead of giving into his nervousness about the Romantics' commitment to the life of things, Cavell cautiously explores its value. Here he separates himself not just from many of his fellow philosophers but also from many literary critics, who appear similarly uncomfortable with lines like the ones from "Tintern Abbey" that I cited. Softening what seems like animism takes many forms, including questioning Wordsworth's standing among the Romantics, making his disconcerting rapport with things the exception rather than the rule; seeing his attachment to natural forms not as an end in itself but as a means of evading or displacing historical realities-in "Tintern Abbey," "the abbey, the beggars and displaced vagrants, all that civilized culture creates and destroys, gets and spends" (I quote from Jerome J. McGann's reading of the poem in The Romantic Ideology) ${ }^{7}$ and, finally, showing how natural objects in Wordsworth keep dissolving into figures of speech. From this point of view, poetic language, however referential it may at first seem, is "always constitutive, able to posit regardless of presence but, by the same token, unable to give a foundation to what it posits except as an intent of consciousness," as Paul de Man puts it in the "Intentional Structure of the Romantic Image." Intimacy with things ceases to be a problem when there are no extralinguistic things to be intimate with: in de Man's words, "critics who speak of a 'happy relationship' between matter and consciousness"-say in a poet like Wordsworth-"fail to 
realize that the very fact that the relationship has to be established within the medium of language indicates that it does not exist in actuality." 8

Instead of minimizing or apologizing for the Romantics' animism, Cavell, by contrast, makes the most of it. I can best show how he uses it by looking at his reading of The Rime of the Ancient Mariner, where Cavell typically focuses on a line that humanizes nature, in this instance the bird who "loved the man / Who shot him with his bow." Cavell first suggests that the mariner perhaps kills the bird "to establish a connection with it closer, as it were, than his caring for it: a connection beyond the force of his human responsibilities, whether conventional or personal, either of which can seem arbitrary" ("IQO," p. 197). Personal responsibilities here include feeding the bird, caring for it, and maybe even talking to it, as people do with pets. These acts can seem arbitrary; nothing determines whether the bird really loves the man in response or is just humoring him. The mariner would rather put the bird to death than feel shut out of its life or let in only by indirect, merely conventional means such as feeding it. It is as if the mariner cannot tolerate his distance or separation from the bird, as if, in reaction to the discovery of this separateness, the mariner decides "to perpetuate it, radicalize it" by putting the bird forever out of reach (p. 198).

According to Cavell, the mariner's "murdering to connect" links him to the skeptic, who similarly longs for a closer connection to the world and to others. "Closer" typically means more certain or secure, the implication being that what we ordinarily call knowledge, whether of others or of objects, falls short of the real thing. As Cavell remarks, skepticism thus "tends to soberize, or respectify, or scientize itself, claiming, for example, greater precision or accuracy or intellectual scrupulousness than, for practical purposes, we are forced to practice in our ordinary lives" (p. 197). According to this reading of skepticism, the disappointed skeptic fails to find in our everyday occasions for knowing one another and the world the absolute certainty that he seeks. Doubt results from the skeptic's rigor and purity, his refusal to settle for anything less than well-grounded knowledge.

The mariner's killing the bird supports this reading of skepticism but also contests its completeness. Again, the bird "loved the man / Who shot him with his bow." Cavell goes on to suggest that at some level the man knew that the bird loved him, was even absolutely sure of it, despite his apparent longing for a more intimate connection with the bird. He thus may have killed the bird not to radicalize his distance from it, as suggested earlier, but "to silence the bird's claim upon him" (p. 197), 
a claim that is not inaudible but, if anything, too clear. In this light, the mariner's problem becomes not loving "things both great and small," as he later puts it, but letting himself be loved by them-not knowing the bird but acknowledging what he already knows.

The mariner realizes that the bird loves him: this takes me back to what I have been calling the Romantic writers' "animism," by which I have meant an intimacy with the nonhuman world often reserved for people. "Neighboring" the world (in Thoreau), being "next" to it (in Emerson), and seeing into its life (in Wordsworth) all convey the Romantics' assurance in the existence and intelligibility of things. For Cavell, Romanticism here resembles ordinary-language philosophy. In Wittgenstein as well as in Emerson "it is not quite right to say we believe the world exists (though certainly we should not conclude that we do not believe this, that we fail to believe its existence), and wrong even to say we know it exists (while it is equally wrong to say we fail to know this)." Thus our "relation to the world's existence is somehow closer than the ideas of believing and knowing are made to convey." ${ }^{9}$

"Believing in" the existence of setting suns and blue oceans smacks of "believing in" a story about which there may be some doubt. The Romantics are not refuting skepticism-say by asserting "I know that $\mathrm{X}$ exists"-but reconceiving it, or shifting its weight. As Cavell puts it, "we cannot know the world exists," but for the Romantics this means "its presentness to us cannot be a function of knowing. The world is to be accepted; as the presentness of other minds is not to be known, but acknowledged." 10

What philosophy represents as doubt, Romanticism thus recasts as avoidance and even murder. Interpreting skepticism this way has disturbing implications. For philosophy, it means that doubting the world's existence becomes one way of not accepting it, one way of avoiding, or voiding, its presence to us. Put a bit differently, the epistemological problem of knowing the world sidetracks us from the real problem of accepting it, just as the mariner's professed difficulty in knowing whether the bird loves him covers the real difficulties he has in acknowledging the bird's all-too-real claim on him. Contrived epistemological puzzles"How do I know the bird exists or really loves me?"-become a convenient pretext for evading a more urgent and uncomfortable question: "What do I do with a bird that loves me?" As Cavell points out, Romanticism accordingly makes skepticism "less cognitive, so to speak, than philosophy takes it to be"-but at the price, again, of making the skeptic's "object of suspicion uncomfortably ... animate," uncomfortably 
because the external-world skeptic's "object of suspicion" is usually not a seemingly friendly bird but an obviously lifeless ball of wax (as in Descartes) or a table (as in Hume). ${ }^{11}$ Avoiding a piece of wax or murdering a table sounds crazy or superstitious (at best): hence the uneasiness with Romanticism that I have been trying to explain.

But from a Romantic point of view the skeptic is not avoiding a piece of wax; he is avoiding the world's presence by exemplifying it in this fixed, or lifeless, way-by seeing the world in a piece of wax and not in a momentarily singing nightingale, a soaring skylark, a friendly albatross, a setting sun, a sensitive plant, or the meanest flower that blows. Even when the skeptic's object of suspicion is alive, its being alive seems beside the point - the point being to plumb the limitations of knowledge by taking up a best case of knowing, that is, a generic object seemingly in full view. H. H. Price's tomato (in Perception) could have been wax. Putting the life of objects to one side-bracketing it, or treating objects only as objects, essentially fixed and dead (to adapt Coleridge) - becomes another way of murdering them. ${ }^{12}$

Romanticism challenges the skeptic not only to earn his choice of examples but to examine the extraordinary attention that he pays to them. In skepticism, Cavell notes, "it is not just careful description, or practical investigation, underway": "the philosopher is as it were looking for a response from the object, perhaps a shining"-an expectation that brings out the animism, maybe even the madness, implicit in skeptical doubt. ${ }^{13}$ The skeptic's "hyperbolic, unprecedented attention" here (to borrow another phrase of Cavell's) seems more appropriate to the Romantics' animated examples than to the fixities and definites that preoccupy the skeptic: carefully listening to a nightingale that will soon fly away makes more sense than staring at a table that is not going anywhere. By criticizing the Romantics' animism, philosophers may be diverting attention from the animism informing skepticism itself. In suggesting that the philosopher may protest too much, I am thinking of Cavell's remark that 'skepticism's 'doubt' is motivated not by (not even where it is expressed as) a (misguided) intellectual scrupulousness but by a (displaced) denial," in this case an anxious denial of kinship with Romanticism. ${ }^{14}$

In skepticism, Cavell notes, it is "as if 'The world exists' were one more belief, among others, the world one more object among others." "I5 I have been suggesting that Romanticism challenges both assumptions, making accepting the world's presence, not knowing it or believing in it, the problem. What accepting the world looks like and 
why it should be a problem take me beyond the scope of this article, though not, I should add, beyond Romanticism. I am more interested here in showing that the Romantic, having defined the problem this way, is always in the vulnerable position of appearing to challenge our need for knowledge. As Shelley says in A Defence of Poetry,

We have more moral, political and historical wisdom than we know how to reduce into practice: we have more scientific and economical knowledge than can be accommodated to the just distribution of the produce which it multiplies. The poetry in these systems of thought, is concealed by the accumulation of facts and calculating processes. There is no want of knowledge respecting what is wisest and best in morals, government, and political economy, or at least, what is wiser and better than what men now practise and endure. But we let "I dare not wait upon $I$ would, like the poor cat in the adage." We want the creative faculty to imagine that which we know; we want the generous impulse to act that which we imagine; we want the poetry of life. . . ${ }^{16}$

Cavell makes a similar claim when he notes "it is the thing we do not know that can save us": "what we need is not more knowledge but the willingness to forgo knowing." ${ }^{17}$ Instead of warding off the charge of anti-intellectualism, these comments court it by apparently asking us to reject knowledge, or be satisfied with what we already know.

To make matters worse, writers who want us "to forgo knowing" or "imagine that which we know" end up making extraordinary demands on their readers. The whole point of their work, suggests Cavell, is "to prevent understanding which is unaccompanied by inner change"-to prevent our substituting belief in what they say for being touched or moved by it. These writers (as Cavell says of Wittgenstein) "stun mere belief" or try to disable it, often by dealing with beliefs that seem (as beliefs) pedestrian, sentimental, and otherwise disappointing. ${ }^{18}$ Wittgenstein remarks that "if one tried to advance theses in philosophy, it would never be possible to debate them, because everyone would agree to them" (Philosophical Investigations, §128). Much the same can be said of Romantic poetry, or at least of the Lyrical Ballads. Its stories can seem so flat, its observations-its setting suns and blue skies-so obvious, and its themes so trite.

Belief is not enough as a response to such poetry: there does not seem to be anything to believe, any statements or truths worth extracting and testing. "In asking for more than belief," even in stunning "mere belief," such writing, Cavell notes, invites nothing less than "discipleship," 
by which I think he means that it always at some point says to its reader, "Go thou and do likewise"-take part in what produced the poetry you have read. Even more strongly, you cannot have read-you cannot read-this poetry without participating in it. (Little wonder that Coleridge has the Wedding-Guest depart "like one that hath been stunned, / And is of sense forlorn" after hearing the mariner's tale.) As Wordsworth once noted, "the voice which is the voice of my Poetry without Imagination cannot be heard." ${ }^{19}$ Fearing that his reader will be disappointed in one of his typically prosaic poems ("Simon Lee"), Wordsworth accordingly tells him

O Reader! had you in your mind Such stores as silent thought can bring, O gentle Reader! you would find A tale in every thing.

What more I have to say is short, And you must kindly take it:

It is no tale; but, should you think,

Perhaps a tale you'll make it. (1l. 65-72)

Such a short tale will not come alive unless the reader "kindly" takes it - unless the reader exerts the thought and self-scrutiny that went into its creation. Even more disturbingly, not exerting thought leaves the reader as well as the poem dead, mired in the "savage torpor" that Wordsworth laments in his Preface. It follows for Wordsworth that "to be incapable of a feeling of Poetry in my sense of the word" is to be incapable of feeling and unfit "for all voluntary exertion," which in turn means "to be without love of human nature and reverence for God." 20

These are serious charges. They help explain not just why some readers have bristled at accepting the Romantics as philosophers but why other readers, like Yvor Winters, have felt cheated and even angry, as if the Romantics were trying to justify lazy writing, explain away slipshod beliefs, and otherwise exempt their poetry from criticism by making their reader responsible for what they should have done. Instead of belittling this reaction, I have been arguing that Romantic writing has to leave itself vulnerable to it. Such writing is risky. It risks not only dullness and nonsense but megalomania, self-deception, self-righteousness, and other forms of personal confusion. I think that the Romantics can be defended against these accusations: Wordsworth, for instance, measures our "love of human nature" not by our judgment of his poetry 
but by our response to poetry broadly conceived as creative work. But instead of exonerating the Romantics, I have been trying to show that they have to risk rejection (as anti-intellectual and so on) to bring about inner change.

Commenting on Wittgenstein's soliciting "discipleship," Cavell writes, "I do not see that the faults of explicit discipleship are more dangerous than the faults which come from subjection to modes of thought and sensibility whose origins are unseen or unremembered and which therefore create a different blindness inaccessible in other ways to cure. Between control by the living and control by the dead there is nothing to choose." ${ }^{21}$ By subjection to dead modes of thought and sensibility, I think Cavell may have in mind his early work as a graduate student in philosophy, when he felt victimized by his education, forced to repeat material (such as Russell's Theory of Descriptions) as if it were a password, its "fruitfulness exhausted in [its] correct saying." ${ }^{22}$ Because the Romantic writers try to prevent such a rote response to their workbecause they are interested in animating their readers as well as the world-they still stun English and philosophy departments and make even sympathetic readers wretched and nervous.

University of New Mexico

1. Anyone who generalizes about "the Romantics" or "Romanticism" has to acknowledge the diversity that challenges any definition of these terms. On behalf of my examples of Romanticism here, I will only say that most critics interested in characterizing Romanticism-even such different critics as Northrop Frye, Jerome J. McGann, and M. H. Abrams-at some point take these texts into account.

2. Stanley Cavell, “Genteel Responses to Kant? In Emerson's 'Fate' and in Coleridge's Biographia Literaria," Raritan 3 (1978): 38.

3. Stanley Cavell, "In Quest of the Ordinary," in Romanticism and Contemporary Criticism, ed. Morris Eaves and Michael Fischer (Ithaca: Cornell University Press, 1986), p. 191; cited in text as "IQO." Anthony J. Cascardi explores the moral dimensions of the Romantics' reaction to Kant in "From the Sublime to the Natural: Romantic Responses to Kant," in Literature and the Question of Philosophy, ed. Anthony J. Cascardi (Baltimore: Johns Hopkins University Press, 1987), pp. 101-31.

4. In The Senses of Walden (1972; rpt. San Francisco: North Point Press, 1981), Cavell 
goes so far as to claim that "Walden provides a transcendental deduction of the category of the thing-in-itself" (p. 106).

5. William Wordsworth, "Preface to the Second Edition of Lyrical Ballads" (1800), in Selected Poems and Prefaces, ed. Jack Stillinger (Boston: Houghton Mifflin, 1965), p. 456.

6. Ibid., p. 455.

7. Jerome J. McGann, The Romantic Ideology (Chicago: University of Chicago Press, 1983), p. 88.

8. Paul de Man, The Rhetoric of Romanticism (New York: Columbia University Press, 1984), pp. 6, 8 .

9. Cavell, The Senses of Walden, p. 145.

10. Stanley Cavell, "The Avoidance of Love," in Must We Mean What We Say? (1969; rpt. Cambridge: Cambridge University Press, 1976), p. 324. Reconceiving skepticism, or shifting its weight, are phrases I take from Cavell's The Claim of Reason (New York: Oxford University Press, 1979), p. 45.

11. Stanley Cavell, Disowning Knowledge (Cambridge: Cambridge University Press, 1987), p. 7.

12. I am adapting Coleridge's famous suggestion that the mechanistic understanding (as opposed to the "essentially vital" imagination) deals with "objects (as objects)," that is, as "essentially fixed and dead" (Biographia Literaria, Chapter XIII). If the skeptic deals with objects in this spirit, it follows that he lacks imagination, a conclusion that I think Coleridge, like Shelley and Wordsworth, would be willing to draw. Lacking imagination means (among many other things) living in "that inanimate cold world" vividly described in Coleridge's "Dejection: An Ode."

13. Cavell, Disowning Knowledge, p. 9.

14. Ibid., pp. 5-6. My suggestion here that skeptics are unwittingly Romantic (in their hyperbolic attention to objects) parallels the claim of some writers that philosophy is unwittingly literary (in its reliance on figures of speech). Extending this parallel, I would argue that Romanticism heightens, perhaps even flaunts, what bothers philosophers about literature.

15. Ibid., p. 9.

16. Percy Bysshe Shelley, A Defence of Poetry, in Shelley's Critical Prose, ed. Bruce R. McElderry, Jr. (Lincoln: University of Nebraska Press, 1967), p. 29.

17. Cavell, "The Avoidance of Love," pp. 324-25.

18. Cavell, "The Availability of Wittgenstein's Later Philosophy," in Must We Mean What We Say?, p. 71.

19. William Wordsworth to Lady Beaumont, May 21, 1807, in English Romantic Writers, ed. David Perkins (New York: Harcourt, Brace \& World, 1967), p. 356.

20. Ibid., p. 355.

21. Cavell, "The Availability of Wittgenstein's Later Philosophy," p. 72.

22. Stanley Cavell, Themes Out of School (San Francisco: North Point Press, 1984), pp. $196-97$. 